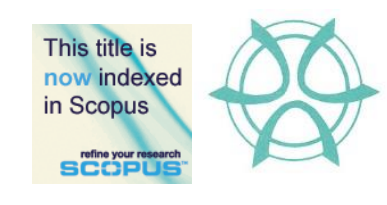

PLANNING MALAYSIA:

Journal of the Malaysian Institute of Planners

VOLUME 16 ISSUE 2 (2018), Page 175 - 185

\title{
HOMESTAY OPERATION UNDER THE PURVIEW OF THE MINISTRY OF TOURISM AND CULTURE OF MALAYSIA: THE CASE OF KELANTAN HOMESTAY OPERATORS
}

\author{
Syahriah Bachok ${ }^{1}$, Hafizah Hasbullah ${ }^{2}$ \& Syakir Amir Ab Rahman ${ }^{3}$ \\ ${ }^{1,2,3}$ Kulliyyah of Architecture and Environmental Design \\ INTERNATIONAL ISLAMIC UNIVERSITY OF MALAYSIA
}

\begin{abstract}
This research outlines the selection, registration, operation and management of formal homestays under the purview of Ministry of Tourism and Culture of Malaysia. Using a case study of Kelantan, the research further elaborates on the inception of such concept in Malaysia, the process and procedures for establishment of homestay operation as well as the maintenance and upholding qualities of the current operational homestays. One of the largest contributing sectors to the Gross National Product in 2015, tourism offers great and various activities to tourists domestic and international alike. One such activities is agrotourism that provide opportunities for the visitors to stay and experience the life of an agriculture community in rural areas of Malaysia. Kelantan being one of the most remote areas in the Peninsula is still rich with natural resources and agricultural produce has the advantage of showcasing the unique attractions to various tourists' types, especially those who were willing to stay overnight or more to properly enjoy and learn about realities of daily life of these selected communities. A gap in the literature identified that research on how these communities were selected to offer such activities while maintaining their identities are scantily available. Hence, this research aims at explaining the processes of registering of homestays and rooms for tourists stay and identifying improvement areas which can be targeted to increase the income receipts from this specialised yet diversified sector.
\end{abstract}

Keywords: homestay, agro-tourism, homeowners, tourism, Kelantan 
Syahriah Bachok, Hafizah Hasbullah, \& Syakir Amir Ab Rahman

Homestay Operation Under the Purview of The Ministry of Tourism and Culture of Malaysia: The Case of Kelantan

Homestay Operators

\section{INTRODUCTION}

Homestay is a term explaining travellers' or tourists' staying in a room or some parts of a complete house in pursuit of experiencing cultural and traditional way of local (often rural) community living. Culture includes lifestyles, values and norms adopted an ethnic group. Normally, a culture depicted is through the language, food and beverages, clothing, behaviour and arts (music, dance and drama), which has a strong influence on the political and organizational structure in place. Cultural tourism is a tourist activity involving the exploration, appreciating and enjoying the culture of other ethnic groups (Ibrahim \& Ahmad, 2009). The factors that encourage the promotion of the development of cultural tourism is the desire to learn, seek and establish one's origin, apart from understanding, deepen and gain new experience about the way of life and customs of a society that is foreign to them. This growing cultural tourism market has been tapped economically by the promotion of the concept of homestay tourism

In Malaysia, the official homestay program is under the purview of the Ministry of Tourism and Culture Malaysia (MOTAC). The main actors of the program are the accommodation on offer, the tourists or travelers willing to stay a minimum of an overnight and also the host families that provides basic necessities for the stay to be enjoyable (MOTAC, 2014). MOTAC adopted a different procedure from those homestay concepts practiced abroad. The Malaysian concept emphasized that tourists stay with host families and daily activities together. In some parts of the globe, the concept applies just simply when a tourist stays and enjoys breakfast. In other words, tourists are not involved in village activities together with a host family (Aminudin \& Jamal, 2006). For examples, homestay concept in the United Kingdom and the United States is more concerned with the motivation to improve proficiency in English language skills among students.

This paper highlights the origin of homestay in Malaysia, identifying the key actors of its development, the process of initiating and selecting the prospective owners and accommodation as well as investigating the distribution of income or revenue from the rental receipts. The approach taken by this research is qualitative in nature, limiting itself to only describing and elaborating the subject matters.

\section{CASE STUDIES}

In Malaysia, homestay development is partially developed around agro-based industry including small rural centres in Felda settlements. The program was first launched in 1995 at Temerloh, Pahang by the then Minister of Culture, Arts and Tourism Malaysia. It was a program under the Rural Tourism Master Plan, which aimed to encourage the participation of rural communities in the tourism sector. Homestay accidentally started in the early 1970s by a local resident who was known as Mak Long in a Cherating village, Pahang. She began providing 
PLANNING MALAYSIA

Journal of the Malaysia Institute of Planners (2018)

accommodation and food (breakfast and dinner) in her house to a group of "drifter" tourists (Hamzah, 1997).

Kelantan is an eastern coast state of Malaysia, rich with unique culture, beautiful beaches, distinctive rural living, active commercial activities, making it very attractive and competitive as a tourist destination. Table 1 outlines the homestay locations and the respective owner operators in Kelantan.

Table 1: List of homestay in Kelantan

\begin{tabular}{llc}
\hline No. & List of homestays in Kelantan & No. of owners \\
\hline 1. & Homestay Kg. Pantai Suri, Tumpat & 20 \\
2. & Homestay Renok Baru, Gua Musang & 20 \\
3. & Homestay Bukit Jering, Jeli & 20 \\
4. & Homestay Kg. Kubang Telaga, Bachok & 32 \\
5. & Homestay Kg. Batu Papan, Gua Musang & 12 \\
6. & Homestay Seterpa, Kota Bharu & 29 \\
7. & Homestay Kg. Jelawang, Dabong & 9 \\
8. & Homestay Kemunchup, Machang & 10 \\
\hline & TOTAL & 152 \\
\hline
\end{tabular}

The figure below shows the annual tourists arrival, staying in Kelantan's homestay. It can be argued that while tourists' arrival to Kelantan was plenty, some 5\% from the total Malaysian statistics (26.76 millions), the demand for homestays was slightly unpromising, with stayers ranging around 3000 to less than 11,000 annually (MOTAC, 2016).

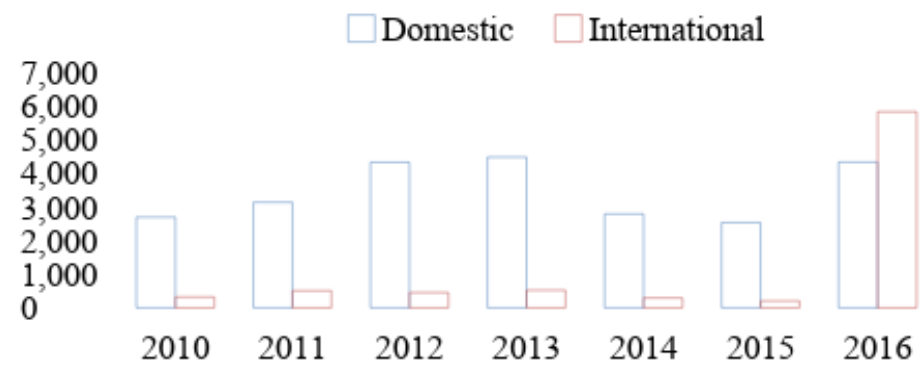

Figure 1: Homestay tourist arrival in Kelantan Source: MOTAC, 2016 
Syahriah Bachok, Hafizah Hasbullah, \& Syakir Amir Ab Rahman

Homestay Operation Under the Purview of The Ministry of Tourism and Culture of Malaysia: The Case of Kelantan

Homestay Operators

\section{METHODOLOGY}

The research deployed two data gathering methods namely primary and secondary. Primary data collection was conducted by field study site visits, identifying the infrastructure and homestay operations while interviews were carried out with officers from relevant agencies, confirming the processes and procedures of selection, operation, monitoring and regulating the homestays. As such, focus group discussion were undertaken from August, 2016 until February 2017 at homestay locations as well as at the offices of the relevant agencies. In total, this research collected 54 interviews with homestay owners.

\section{DATA ANALYSIS AND RESULTS}

\section{Homestay Registration and Operation}

The homestay program is usually run by the local residents in the rural areas. The official homestays, as recognized by the ministry has to undergo various processes and procedures, established under statutes of various Ministries. The most important agency is MOTAC. It will only issue recognition award and license to house owner who fulfils the homestay criteria and regulation. These criteria include adequate facilities for tourists such as a separate bedroom and bathroom and accessibility to the main road. The owners also having no history of criminal record and not suffering from any communicable diseases and high standard of hygiene. MOTAC also provides directions, policies and guidelines for the development of Homestay program, provides funds for tourism infrastructure development, grants to upgrade homes of homestay owner, market and promote through Tourism Malaysia and work closely with state agencies such as State Tourism Action Council, Economic Planning Unit.

The second agency is the Ministry of Rural and Regional Development (MRRD), responsible for providing the infrastructure for rural development such as public toilets, community multi-purpose halls, public walkways, improved landscape and jetty (MOTAC, 2016). Institute for Rural Advancement (INFRA) is a training institute under MRRD that provides training for the rural community including homestay operators as well as the Village Security \& Development Committee (JKKK) (MOTAC, 2016).

Malaysian Tourism Information Centre or MATIC is another important agency. State Office of Tourism Malaysia's responsibility is promoting and providing information relevant to homestays and tourist destinations, facilities and amenities. Tourism Industry Act 1992 is the statutes focusing on the aspects of transportation, food, price and other things related to program packages. MOTAC audit duration and courses were conducted to ensure compatibility and quality levels are consistent over the years. MOTAC has always taken initiatives to avoid confusion of services offered by registered homestays under the 
PLANNING MALAYSIA

Journal of the Malaysia Institute of Planners (2018)

Ministry, and to curb issues of non-registered homestay. These include (MOTAC, 2014):

i. Close cooperation with the local authorities to address the issue of illegal homestay operators;

ii. Advising local authorities to be more stringent in issuing business license for accommodation premises when using the term "homestay";

iii. Advising company Commission of Malaysia (Suruhanjaya Syarikat Malaysia-SSM) to consult MOTAC of any application for company registration using the term "homestay"; and

iv. Imposition of the usage of the Malaysia Homestay Experience Logo under the provisions of the Trade Marks Act 1976 and Trade Marks Regulations 1997 by the registered homestay for quality, safety and security assurance

MOTAC's visit and recognition were important in sustaining and maintaining the quality of homestays in Kelantan. The visit runs every three years. A village selected to involve in the homestay program must meet specific criteria and comply with guidelines issued by MOTAC in order for homestay programs to be carried out effectively and efficiently. Recognition process started from the date when an application to join the homestay program was made. The homestay program is open to all Malaysians owning or occupy a home in Malaysia. Malaysians that wish to join the homestay program are required to register with MOTAC.

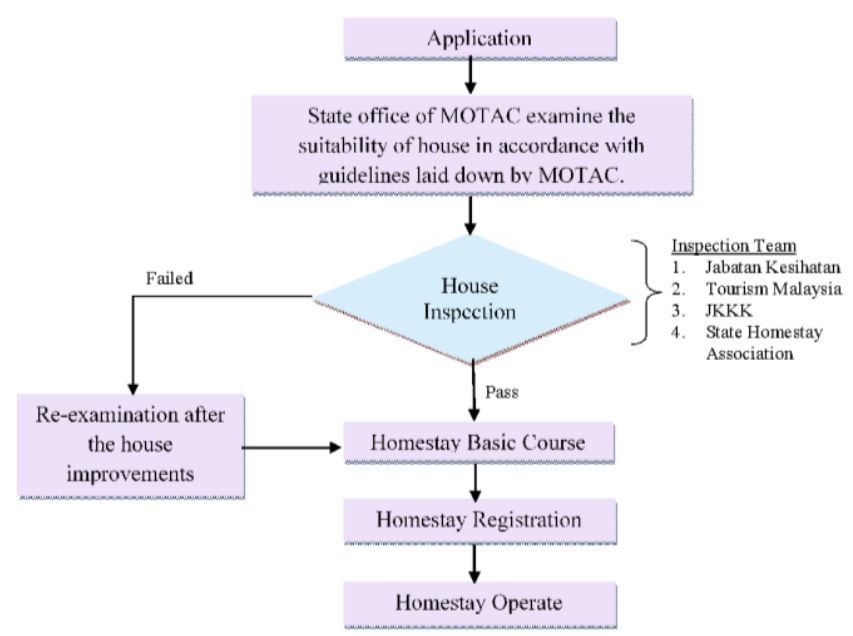

Figure 2: Flow chart homestay registration process 
Syahriah Bachok, Hafizah Hasbullah, \& Syakir Amir Ab Rahman

Homestay Operation Under the Purview of The Ministry of Tourism and Culture of Malaysia: The Case of Kelantan

Homestay Operators

Figure 2 shows the flow chart homestay registration process. Before registering with MOTAC, each homestay owner has undergone and must pass a house inspection that was supervised by MOTAC. The agencies involved with the inspection are the Department of Health, Tourism Malaysia, Village Security \& Development Committee (JKKK) and State Homestay Association. Other than that, Homestay owners also need to attend Homestay basic course organized by (INFRA and Ministry of Rural and Regional Development.

Ministry of Agriculture (MOA) is the fourth main agency involved. Agricultural products were amongst local attractions since the venues of homestay were located in rural areas. Hence, the MOA focuses in financial and technical assistance to improve the agriculture activities in homestays area (MOTAC, 2016).

Additionally, individual homestay operation must possess specific characteristics (Table 2) for homestay programs as prescribed by the MOTAC (2016). During ground truth surveys and field study visits, these were observed and confirmed

Table 2: Characteristics for homestay programs

\begin{tabular}{|c|c|}
\hline $\begin{array}{l}\text { Residential } \\
\text { location }\end{array}$ & $\begin{array}{l}\text { The location should be in the strategic area in terms of } \\
\text { transportation and free from pollution. Have a suitable } \\
\text { environment besides displaying the lifestyle of Malaysian } \\
\text { society. }\end{array}$ \\
\hline Basic facilities & $\begin{array}{l}\text { The guest bedroom is separated from the other bedrooms in the } \\
\text { house. To ensure the comfort of the host's family members and } \\
\text { guests, the maximum number of rooms permitted for visitors is } \\
\text { limited to four decent sized bedrooms. Usually, one bathroom is } \\
\text { attached inside the guest room. The visitors' comfort should be } \\
\text { prioritized and the premises must have proper bathrooms, toilet } \\
\text { facilities, dining and living room as well as other basic amenities. } \\
\text { Preparation and supply of meals, towels, and other things upon } \\
\text { the visitors' request. Basic facilities should be well maintained } \\
\text { to ensure the cleanliness of the premises and the comfort of the } \\
\text { visitors. }\end{array}$ \\
\hline Cleanliness & $\begin{array}{l}\text { The home area should be clean and clear of rubbish. Efficient } \\
\text { waste disposal and drainage should be ensured to avoid } \\
\text { unpleasant odors. }\end{array}$ \\
\hline Safety & $\begin{array}{l}\text { Insurance coverage is necessary to protect visitors. For tour } \\
\text { groups brought in by travel agencies, insurance coverage should } \\
\text { be handled by the tour company. The host is advised to take out } \\
\text { an insurance policy from any registered insurance company for } \\
\text { the protection of individual visitors. }\end{array}$ \\
\hline $\begin{array}{l}\text { Guidelines for } \\
\text { food preparation }\end{array}$ & $\begin{array}{l}\text { The storage and handling of food and running of food premises } \\
\text { must be paid close attention. The cleanliness of these premises } \\
\text { needs to be maintained and all unused containers (boxes, bottles, }\end{array}$ \\
\hline
\end{tabular}




\begin{tabular}{ll}
\hline & $\begin{array}{l}\text { etc.) which can become a breeding ground for 'vermin' such as } \\
\text { mice and insects should be disposed off properly. Garbage must } \\
\text { also be collected and disposed off frequently while waste } \\
\text { disposal areas and containers must be cleaned regularly. }\end{array}$ \\
\hline $\begin{array}{l}\text { Equipment and } \\
\text { appliances }\end{array}$ & $\begin{array}{l}\text { All equipment and appliances used in the preparation and } \\
\text { handling of food should be appropriate to prevent food } \\
\text { poisoning. Equipment and appliances should be washed after use } \\
\text { and kept in sanitary conditions. }\end{array}$ \\
\hline Source: MOTAC, 2016 &
\end{tabular}

The clustered homestay under MOTAC were observed to have possessed these qualities too (MOTAC, 2016):

i. Have a minimum number of 10 registered Homestay providers within the clustered Homestay to reflect community involvement and cohesion;

ii. Be accessible to any mode of transportation and communication;

iii. Embrace think and act tourism mind-set;

iv. Maintain a high level of security, safety and cleanliness;

v. Offer rural based and traditional activities such as fishing, traditional games, cultural performances and rubber tapping (agro-based, eco, cultural-based tourism).

Participation in a homestay program would to gain knowledge of external culture, acquire skills in greeting and receiving guests and be able to expand participation in their Small Medium Enterprise (SME) business as witnessed during ground truth survey and field study visits.

\section{Issues and Problems}

During interview sessions with the 54 owners and operators of homestays, the research team has discovered a few problems faced by them. Such as, the decreasing number of tourist arrivals which could not generate additional income as expected or sustain Homestay operation. Based on current scenario of abundance of accommodation, majority of them were not satisfied with the operating of unregistered homestays (not registered with MOTAC) and other types of accommodation. This is because homestay operators have to compete with these competitors. The misused or manipulated concept of homestays is another issue facing the operators. Abusive activities by commercial operators illegally calling themselves as homestays have negatively impacted the income and revenue of the officially registered homestay communities.

Another issue was the miscommunication between owners and visitors. Failure in good communication would cause difficulties in interaction with the foreign tourists. Good communication between both parties increases the intensity and enjoyment of the homestay experience. Whenever both parties are impeded by a lack of communication skills or mastering of an international 
Syahriah Bachok, Hafizah Hasbullah, \& Syakir Amir Ab Rahman

Homestay Operation Under the Purview of The Ministry of Tourism and Culture of Malaysia: The Case of Kelantan

Homestay Operators

language, the intensity and goals of the program are affected (Pusiran \& Xiao, 2013). Communication skill is important for each homestay owner because they have to interact with tourists of either from within or outside the country., Homestay owners interested to learn English as learning English would not only benefit them but also would enhance the tourism industry in their area. They would be able to communicate with the foreigners.

During the interview, it was found that the homestay communities also faced problems such as the lack of commitment and cooperation among some operators, the disintegrated community and lack of leadership quality. For homestays to work, the relationship between the communities must be very strong as it is a purely service-oriented concept of tourism. Cooperation and coordination to run homestay program among community is a must, otherwise it can bring about conflicts in the future.

Due to differences in culture, some tourist behavior is perceived by operators as culturally inappropriate that may create socio-cultural problems in the area. Since tourists stay in a local social environment, they need to be respectful to preserve local traditions, stimulates cultural exchange and cooperate with the local residents

\section{Room Distribution and Allocation}

The process of selection of houses/rooms on offer for different visitors was normally randomly distributed between/among the homestay owners (Figure 3). Important and prominent leaders of the group such as lecturer, teacher or group leader, would stay in the house of the chairman of association/the head of JKKK or special chalets provided by homestays. Usually, two persons will occupy/share a room. In order to ensure fair visitors' distribution among all participants, the chairman of association or head of JKKK was a person in charge in allotting guests to the different homestays. Visitors were divided among the owners who had the lowest amount of visitors for that period. Whenever a member was unable to be a host because of family affairs, holidays or any personal reasons, the next member in line was selected. Walk-in guests were referred to the chairman of association or head of JKKK by the tourism office and he/she would provide/allocate the visitors/guests to various possible homestay options. 


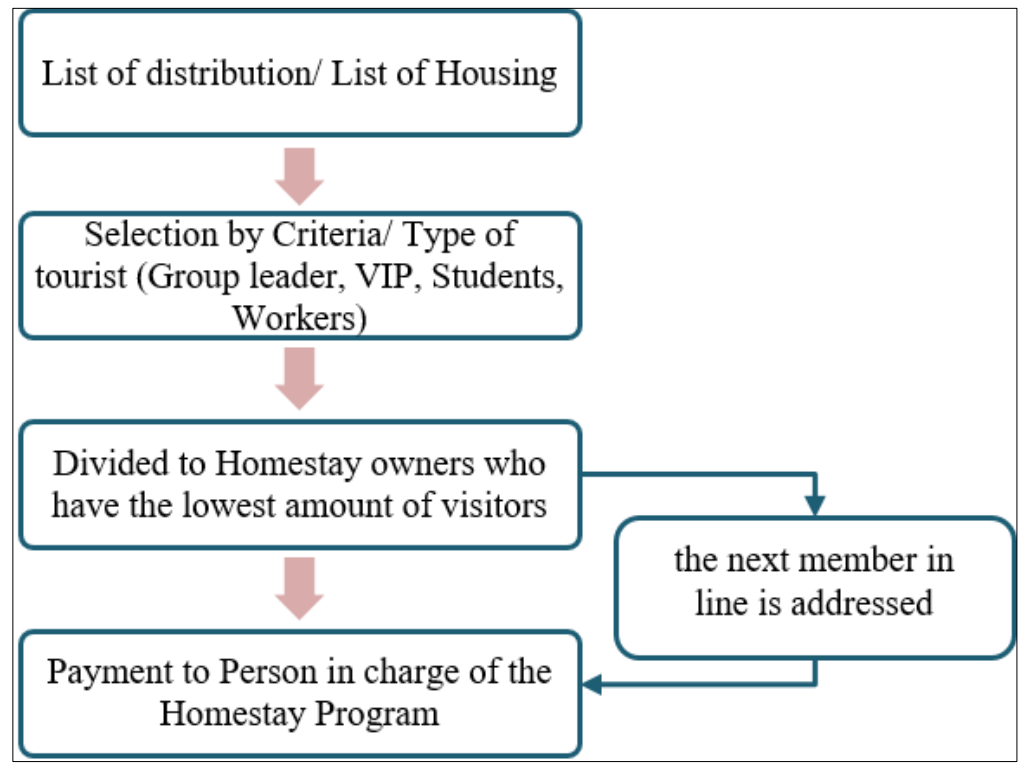

Figure 3: Room selection and distribution

\section{Homestay Income and Receipts Distribution}

During the focus group discussion, the researcher found out that these clusters were managed by coordinating groups, such as the homestay program committee. Some homestay program committees were the extensions of the Village Security \& Development Committee (JKKK) and others were registered co-operatives. Money received from rental of rooms in homestay was distributed in systematic manners (refer Figure 4). Most tourists/visitors came in groups and the package for the homestay program for two days, one night inclusive of meals, ranging from RM60-90 (USD 15-23), depending on the activities that were included in the itineraries. Payments received from a group of visitor would then be credited into Homestay Association or Committee's account. Each homestay owner was paid RM30-150 (USD 8-35) for each hosted visitor per night. Profits were used by the committee marketing activities and for the procurement of supplies and material needed for subsequent activities.

An approximation of annual income by homestay source can be calculated by the participants. However, these figures should not be the taken as the guiding amount of annual overall income of the participants, as they may have a formal day job, and side incomes from other business and activities. Figure 5 shows that homestays activities were only generating from RM101-RM300 annually (as reported by 33.43 percent of respondents). Less than 3.4 percent had homestays generating more than RM1,000 annually. 
Syahriah Bachok, Hafizah Hasbullah, \& Syakir Amir Ab Rahman

Homestay Operation Under the Purview of The Ministry of Tourism and Culture of Malaysia: The Case of Kelantan

Homestay Operators

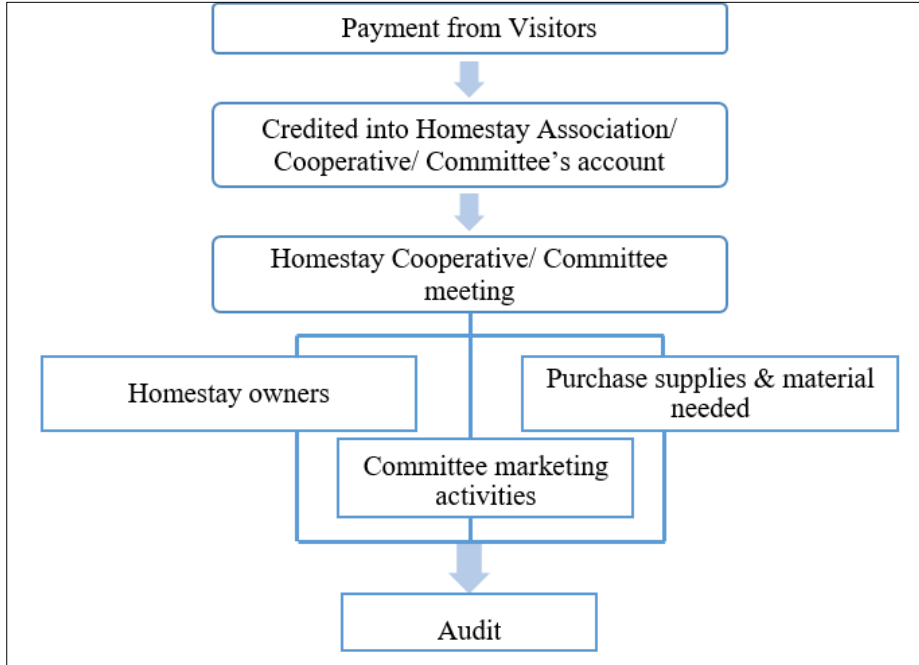

Figure 4: Income / revenue distribution flow

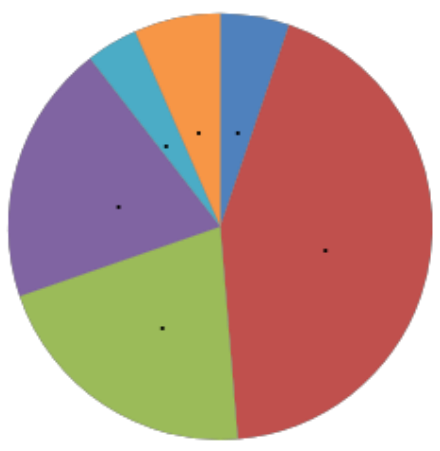

RM100 Below

RM101-300

RM301-600

RM601-1000

RM1001 Above

$\mathrm{N} / \mathrm{A}$

Figure 5: Kelantan homestay income

\section{CONCLUSION AND RECOMMENDATIONS}

To conclude, homestays are potential income sources for rural communities, commodifying their unique culture and agricultural produce to be marketed as tourism products. However, there exist numerous agencies and multi-layered and -faceted sets of rules and regulations of the operation of homestay program that can sometime put unnecessary pressure on the owners. These agencies should be focusing on providing and upgrading the hard infrastructure such as road networks, telecommunications, renovation and upgrading schemes of buildings, structures and communal facilities to be used by tourists staying with host families. 
PLANNING MALAYSIA

Journal of the Malaysia Institute of Planners (2018)

Confusion and abusive use of the concept homestays by illegal commercial operators were deemed as threats to the homestay owners registered with the authorities. In order to sustain and ensure the longevity of these rural homestays, they must strategies to rigorously promote and package their unique and distinctive rural lifestyle and remote locations, at both regional and global levels. In addition to that, the government specifically MOTAC need to control the illegal commercial operators by increasing resources as well as strengthening legislations and technical capacities to enhance the effectiveness of implementation and enforcement.

Quality control on selection process and operation have been very tight, but income remained low that some of the homestay have ceased operations, partly due to hefty competition. Hence, in addition to central and state agency promotion and packaging, owners and operators must equip themselves with skills and technical know-how to face contemporary challenges and issues described earlier.

\section{ACKNOWLEDGEMENTS}

This work was supported in part by International Islamic University of Malaysia under Grant Nos. SP16-034-0247.

\section{REFERENCES}

Aminudin, N., \& Jamal, S. A. (2006). Homestay Selangor: Keunikan dan pengalaman pengusaha. Shah Alam: Pusat Penerbitan Universiti, Universiti Teknologi MARA.

Hamzah, A. (1996). The evolution of small-scale tourism in malaysia: problems, opportunities and implications for sustainability. In M. J. Stabler, Tourism and sustainability: Principles to practice (pp.199-217). Wallingford: CAB International.

Ibrahim, J. A. \& Ahmad, M. Z. (2009, June). Program homestay pemangkin pertumbuhan ekonomi luar bandar, kajian kes: Negeri-negeri utara Semenanjung, Malaysia. Persidangan Kebangsaan Ekonomi Malaysia (PERKEM IV). June 2-4, 2009, Kuantan Pahang, Malaysia.

Ministry of Tourism and Culture [MOTAC] (2014). Malaysia homestay statistics. Ministry of Tourism and Culture [MOTAC] (2016). Malaysia homestay statistics.

Pusiran, A. K., \& Xiao, H. (2013). Challenges and community development: A case study of homestay in Malaysia. Asian Social Science, 9(5), 1-17. 